\title{
Pola Ijtihad Fatwa Dewan Syari'ah Nasional MUI tentang Produk Perbankan Syari'ah
}

\author{
Oleh: Rahmani Timorita Yulianti*
}

\begin{abstract}
The following article tries to investigate the main problem concerning the form of intellectual exercise and some background factors that influence on fatwa legislation that conducted by Indonesian Syariah Council (Dewan Syariah Nasional) of the Council of Indonsian Ulama (MUI) regarding syariah banking product. The result of this research revealed that the ijtihad pattern that used is analogical reasoning (ta'lili or qiyasi), and that of public welfare consideration (istislahi). Some factors that involving are to accomodate society willing to avoid the interest, and its instead of it is partnership, the product based on Islamic moral values, preventing invironment destruction and moral decadence
\end{abstract}

Keywords: ijtihad, fatwa, syariah, ulama, dan pola.

\section{Pendahuluan}

Salah satu perbedaan pokok antara perbankan syari'ah dengan perbankan konvensional adalah adanya larangan riba (bunga). Bagi perbankan Syari' ah. riba dilarang sedangkan jual beli (al bay') dihalalkan. Dengan demikian membayar dan menerima bunga pada uang yang dipinjam dan meminjamkan dilarang. Sebagai pengganti dari mekanisme bunga, sebagian ulama meyakini bahwa

* Dosen tetap Program Studi Ekonomi Islam FIAI UII dan Reseacher pada Pusat Studi Islam (PSI) UII Yogyakarta 
dalam pembiayaan proyek-proyek individual dan lembaga, instrumen yang paling baik adalah bagi keuntungan dan kerugian (profit and loss sharing). Meskipun mekanisme bagi hasil saat ini telah menjadi metode unggulan bagi perbankan Syari'ah, namun perlu ditegaskan bahwa posisi Syari'ah yang juga berbasis pada prinsip kebebasan berkontrak adalah fleksibel. Semua jenis kontrak atau transaksi pada prinsipnya diperbolehkan asal sepanjang tidak berisi elemen riba dan atau gharar. Namun demikian telah ada konsensus yang kuat di antara para ulama bahwa operasi perbankan Syari'ah harus berdasarkan sistem bebas bunga. Gharar dapat didefinisikan sebagai suatu situasi di mana para pihak yang berkontrak tidak menguasai informasi tentang subyek kontrak mereka. Oleh karena itu tipetipe future contracts dimana satu pihak tidak menujukkan penguasaan terhadap komoditi yang ditransaksikan, apalagi dengan tanpa penyerahan barang (non delivery trading contract), adalah tidak sah. Namun demikian, pihak yang dikenal sebagai produsen suatu barang boleh melakukan transaksi pesanan melalui bay'al salam yaitu transaksi spot dengan penyerahan barang kemudian. Dalam kerangka itulah Dewan Syari'ah berfungsi untuk memberikan advis kepada perbankan Syari'ah guna memastikan bahwa bank Syari'ah dalam operasionalnya tidak terlibat dalam kontrak yang mengandung unsur-unsur yang tidak disetujui oleh Islam.

Tulisan ini merupakan satu di antara usaha untuk turut serta dalam memberikan kontribusi kepada perbankan Syari'ah agar dapat mengembangkan jenis-jenis produk dan jasa dalam rangka memenuhi kebutuhan masyarakat berdasarkan pada fatwa DSN MUI tentang produk perbankan Syari'ah mulai tahun 1999 sampai tahun 2006.

Kajian seperti ini, sepengetahuan penulis belum pernah dipublikasikan oleh para penulis terdahulu. Dengan demikian permasalahan dalam tulisan ini perlu dikaji seoptimal mungkin, sebatas sumber-sumber yang telah terkumpul. Dalam kerangka itulah tulisan ini ${ }^{1}$ mencoba mendeskripsikan dua hal yaitu pola ijtihad apa yang dipergunakan dalam penetapan fatwa Dewan Syari'ah Nasional MUI tentang produk perbankan Syariah ? Serta faktor apa yang melatarbelakangi pertimbangan penetapan fatwa Dewan Syari'ah Nasional MUI tentang produk perbankan Syariah tersebut?

${ }^{1}$ Walaupun ada karya Mohammad Atho Muzdhar (1993), Fatwa-fatwa Majelis Ulama Indonesia, (Jakarta : INIS), berasal dari disertasi yang bersangkutan, tapi sifatnya jauh berbeda dengan corak peneliti ini. Muzdhar lebih memfokuskan pada Pemikiran Hukum Islam di Indonesia, 1975 - 1988. Selain itu terdapat makalah tulisan Maftukhatusolikhah (2002), Telaah Atas Fatwa DSN - MUI/IX/2000, (Yogyakarta: P3EI), memfokuskan pada pemberian sanksi terhadap nasabah mampu yang menundanunda pembayaran hutangnya dalam perspektif ulama fiqh. 


\section{Pola Ijtihad Penetapan Hukum Islam.}

Aktivitas perbankan Syari'ah di Tanah Air berkembang sangat dinamis semenjak pemerintah memberlakukan UU No.10 Tahun 1998 dan UU No.23 Tahun 1999 tentang Perbankan dan Bank Indonesia. Oleh karenanya, banyak bermunculan bank-bank Syari'ah baru mendampingi PT BMI yang selama ini merupakan pemain tunggal dalam pasar perbankan Syari'ah di Tanah Air.

Perkembangan yang menggembirakan tersebut diikuti oleh langkah Majelis Ulama Indonesia (MUI) dengan mendirikan Dewan Syari'ah Nasional (DSN) pada tahun 1999. Dasar pendirian DSN ini adalah seiring perkembangan lembaga-lembaga keuangan syari'ah di Tanah Air yang di dalamnya terdapat dewan-dewan pengawas Syari'ah. Karenanya, berdasarkan SK. MUI No.Kep.754/ II/1999, MUI memandang perlu adanya dewan syari'ah yang bersifat nasional yang mempunyai tugas di antaranya adalah mengeluarkan fatwa atas jenis-jenis produk lembaga keuangan Syari'ah seperti perbankan Syari'ah, asuransi syari'ah dan lain-lain, agar sesuai dengan nilai-nilai syariah. Sehubungan dengan hal tersebut, tulisan ini difokuskan bukan kepada Dewan Syari' ah Nasional MUI dari segi peranannya secara umum dalam masyarakat, melainkan dari segi fatwanya. Karena fatwa itulah yang merupakan substansi pemikiran hukum Dewan Syari'ah Nasional MUI. Selain itu fatwa adalah salah satu dari lima produk pemikiran hukum Islam yang dipelajari dan diteliti seperti, kitab-kitab fiqh, Keputusan Pengadilan Agama, perundangan yang berlaku di negara muslim, kompilasi Hukum Islam dan Fatwa. ${ }^{2}$ Fatwa sebagai salah satu produk pemikiran hukum Islam, erat sekali hubungannya dengan persoalan-persoalan kemasyarakatan. Oleh karena itu fatwa Dewan Syari'ah Nasioanl MUI pada dasarnya adalah hasil interaksi antara si pemikir hukum dengan lingkungannya ${ }^{3}$

Sehubungan dengan penetapan hukum dalam fatwa Dewan Syari'ah Nasional MUI maka terdapat tiga pola ijtihad yang dapat dirujuk yaitu pola bayani (kajian semantik), pola Qiyasi (pola ta'lili) yaitu penentuan illat dan pola istislahi (pertimbangan kemaslahatan berdasarkan nash umum) ${ }^{4}$

Ke dalam pola pertama dimasukkan semua kegiatan yang berkaitan dengan kajian kebahasaan (semantik): kapan sesuatu lafal diartikan secara majaz; bagaimana memilih salah satu dari lafal musytarak (ambiguitas), mana ayat yang umum, yang diterangkan ('am, mubayyan, lex generalis) dan mana pula yang khusus, yang menerangkan (khas,mubayyin, lex specialis), mana ayat yang qat'i (yang artinya tidak dapat berubah) dan mana pula yang zani, kapan sesuatu perintah dianggap untuk wajib dan kapan pula untuk sunat, kapan larangan itu untuk haram dan kapan pula untuk makruh dan seterusnya.

${ }^{2}$ Mohammad Atho Mudzhar (1998), Pendekatan Studi Islam dalam Teori dan Praktek, (Yogyakarta: Pustaka Pelajar Offset), hal. 245.

${ }^{3}$ Ibid, hal. 103 - 125.

${ }^{4}$ Ad Dawalibi Muhammad Ma'ruf (1965), al-Madkhal ila 'ilm Usul al-Fiqh, (Beirut: Dar al- 'Ilm lil-Malayin), hal. 405. 
Ke dalam pola kedua dimasukkan semua penalaran yang menjadikan 'illat (keadaan atau sifat yang menjadi tambatan hukum) sebagai titik tolaknya. Di sini dibahas cara-cara menemukan 'illat, penggunan 'illat di dalam qiyas dan istihsan serta pengubahan hukum itu sendiri sekiranya ditemukan 'illat baru (sebagai pengganti yang lama).

Pola ketiga mengidentifikasi masalah-masalah yang tidak mempunyai nas khusus sebagai rujukan. Dalam pola ini, ayat-ayat umum dikumpulkan guna menciptakan beberapa prinsip (umum), yang digunakan untuk melindungi atau mendatangkan kemaslahtan tertentu. Prinsip-prinsip tersebut disusun menjadi tiga tingkatan (daruriyat, kebutuhan esensial; hajiyat, kebutuhan sekunder dan tahsiniyat, kebutuhan kemewahan). Prinip umum ini dideduksikan kepada persoalan yang ingin diselesaikan.

Di dalam praktik, biasanya pola ta'lili digunakan apabila ada perasaan tidak puas dengan pola bayani. Mungkin untuk memperkuat argumen, tapi mungkin juga untuk mengalihkannya kepada kesimpulan lain agar terasa lebih logis dan lebih berhasil guna. Pola isti slahi sesuai dengan keadaannya, baru digunakan bila tidak ada dalil khusus hanya berhubungan dengan persoalan-persoalan baru yang biasanya muncul karena penggunaan teknologi dan kemajuan ilmu pengetahuan. ${ }^{5}$

Sesungguhnya ketiga pola ijtihad bayani, ta'lili atau istislahi tersebut dalam kaitan dengan maslahat sebagai tujuan tasyri' merupakan pola dalam rangka memahami tujuan penetapan hukum Islam, yaitu kemaslahatan hidup dan kehidupan manusia, terutama dalam bidang mu'amalah. Dalam kaitan ini penggunaan ketiga pola ijtihad di atas dapat diterapkan secara bersamaan, yaitu memahami nas, menelusuri 'illat nash dan memikirkan secara mendalam tentang kemaslahatan yang merupakan tujuan penetapan hukum Islam ${ }^{6}$

Dalam hubungan dengan rekayasa sosiaal karena kemajuan teknologi sekarang, ketiga pola di atas dapat digunakan. Persoalan utama pengembangan dan perubahan ini tidak terletak pada perangkat lunak (pola penalaran) dan tidak juga pada perangkat keras (Al- Qur'an dan Sunah), tetapi lebih banyak terletak pada kualitas operator (mujtahid) dan keberaniannya bereskperimen. Dengan kualitas dimaksud diperlukan penguasaan terhadap usul-fiqh, Al - Qur'an, Hadis, bahasa Arab dan sampai tingkat tertentu ilmu modern (misalnya antropologi dan sosiologi untuk hukum kekeluargaan). Sedangkan eksperimen dapat dicontohkan dengan pertanyaan yang menggunggat kemapanan atau upaya mendekati ayat dan hadis dengan kaidah lain (baru) yang sebelumnya tidak digunakan. ${ }^{7}$

${ }^{5}$ Amir Mu'allim dan Yusdani (1997), Ijtihad Suatu Kontroversi: Antara Teori dan Praktik, (Yogyakarta: Titian Ilahi Press), hal.119.

${ }^{6}$ Amir Mu'allim dan Yusdani (2001), Konfigurasi Pemikiran Hukum Islam, (Yogyakarta: UII Press), hal. 64.

7 Ibid. 


\section{Profil Dewan Syari'ah Nasional}

Dewan Syari' ah Nasional (DSN) adalah salah satu lembaga yang dibentuk oleh MUI untuk menangani masalah-masalah yang berhubungan dengan aktivitas lembaga keuangan syari'ah. Pembentukan Dewan Syari'ah Nasional merupakan langkah efisiensi dan koordinasi para ulama dalam menangani isuisu yang berhubungan dengan masalah ekonomi/keuangan. DSN diharapkan dapat berfungsi untuk mendorong penerapan ajaran Islam dalam kehidupan ekonomi. Oleh karena itu, Dewan Syari'ah Nasional akan berperan secara proaktif dalam menanggapi perkembangan masyarakat Indonesia yang dinamis dalam bidang ekonomi dan keuangan. Dewan Syariah Nasional (DSN) sejak dibentuknya, Februari 1999, telah melakukan berbagai program kerjanya sesuai dengan tugas dan wewenang yang diberikan. Program tersebut dapat dijabarkan sebagai berikut:

\section{A. Mengeluarkan Fatwa}

Dewan Syari'ah Nasional telah mengeluarkan fatwa-fatwa yang menjadi landasan bagi ketentuan/peraturan yang dikeluarkan oleh instansi yang berwenang, seperti Departemen Agama, BAPEPAM, dan Bank Indonesia. Fatwa tersebut sifatnya mengikat terhadap Dewan Syari'ah di masing-masing lembaga keuangan syari'ah dan manjadi dasar tindakan hukum pihak terkait.

Hingga tahun 2006, fatwa yang telah dikeluarkan oleh DSN sebanyak 53 fatwa yang meliputi fatwa tentang Giro, Tabungan, dan Deposito yang berdasarkan Syari'ah, fatwa tentang Murabahah, jual Beli Salam, Istishna, Pembiayaan Mudharabah (Qiradh), Musyarakah, Ijarah, Wakalaf, Kafalah, Hawalah, Uang Muka dalam Murabahah, Sistem Distribusi Hasil Usaha dan LKS, Prinsip Distribusi Hasil Usaha dalam LKS, Diskon dan Mudharabah, Sanksi atas Nasabah mampu yang menunda-nunda Pembayaran, Pencadangan Penghapusan Aktiva Produktif dalam Lembaga Keuangan Syari'ah, Al-Qard, Pedoman Pelaksanaan Investasi untuk Reksadana Syariah dan lain-lain.

\section{B. Mengeluarkan Surat-surat Keputusan}

DSN juga telah menerapkan beberapa keputusan/ketentuan yang akan menjadi acuan bagi lembaga keuangan syari'ah. SK yang telah dikeluarkan antara lain: SK tentang Pedoman Dasar dan Pedoman Rumah Tangga (PD-PRT) DSN. SK tentang Petunjuk Pelaksanaan Penetapan Anggota DPS pada Lemmbaga Keuangan Syari'ah (LKS) dan SK tentang Dana Kepesertaan dan Iuran Buanan bagi Perankan dan Lembaga Keuangan Syari'ah. 
Rahmani Timorita Yulianti: Pola Ijtihad ...

\section{Memberi Rekomendasi kepada LKS}

DSN-MUI telah mengeluarkan surat rekomendasi nama-nama yang duduk sebagai Dewan Pengawas Syari'ah (DPS) pada suatu lembaga keuangan syari'ah.

\section{Pola Ijtihad dan Latar Belakang Pertimbangan Penetapan Fatwa Dewan Syari'ah Nasional.}

Fatwa yang dikaji oleh penulis adalah 19 fatwa dari 53 fatwa. Adapun fatwa lainnya tidak dikaji karena penulis menfokuskan kepada fatwa tentang produk perbankan syari'ah baik pengumpulan, pembiayaan dan jasa.

\section{A. Fatwa Tentang Produk Penghimpunan Dana yaitu :}

\section{Fatwa tentang Giro}

Ditetapkan oleh DSN (Dewan Syari'ah Nasional) dalam rangka untuk memenuhi keperluan masyarakat dalam peningkatan kesejahteraan dan investasi pada masa kini. Giro termasuk salah satu produk perbankan di bidang penghimpunan dana dari masyarakat yang merupakan simpanan dana yang penarikannya dapat dilakukan setiap saat dengan penggunaan cek, bilyet giro, sarana perintah pembayaran lainnya atau dengan pemindahbukuan ${ }^{8}$ Selain itu fatwa tentang giro ini ditetapkan karena tidak semua giro dapat dibenarkan oleh syari'ah. Hanya Giro yang berdasarkan prinsip mudarabah dan wadiah yang direkomendasikan oleh DSN.

Dalil-dalil yang dikemukakan oleh fatwa tentang giro terdiri atas kutipankutipan dari Al-Qur'an dan Hadis, serta alasan menurut akal pikiran. Dalil akal pikiran bagi fatwa tentang giro menyatakan bahwa dalam kenyataan banyak orang yang mempunyai harta namun tidak mempunyai kepandaian dalam usaha memproduktifkannya, sementara itu tidak sedikit pula orang yang tidak memiliki harta namun ia mempunyai kemampuan dalam memproduktifkannya. Oleh karena itu, diperlukan adanya kerjasama di antara kedua pihak tersebut.

Dipandang dari segi metodologi fatwa ini menggunakan dua metode sekaligus, yaitu ijma' dan qiyas. Penggunaan ijma ialah pada peristiwa sejumlah sahabat menyerahkan (kepada orang, mudarib) harta anak yatim sebagai mudarabah dan tidak ada seorangpun mengingkari mereka, sehingga hal tersebut dipandang sebagai ijma. ${ }^{9}$ Sedangkan qiyas digunakan alam menganalogikan antara transaksi mudarabah dengan transaksi musaqah yaitu penyerahan sejumlah harta

${ }^{8}$ Dewan Syari'ah Nasional MUI dan Bank Indonesia (2001), Himpunan Fatwa Dewan Syariah Nasional untuk Lembaga Keuangan Syariah, Edisi Pertama, hal. 01.

${ }^{9}$ Zuhaily (1989), al-Fiqh al-Islamiwa Adillatuhu, 4 / 838. 
dari satu pihak kepada pihak lain untuk diperniagakan dan keuntungan dibagi mereka sesuai kesepakatan.

\section{Fatwa Tentang Tabungan}

Selain untuk peningkatan kesejahteraan dan penyimpanan kekayaan masyarakat, jasa tabungan perbankan syari'ah perlu diadakan fatwanya mengingat kegiatan tabungan tidak semuanya dapat dibenarkan oleh syari'ah. Oleh karena itu dalam fatwa ini DSN hanya memperbolehkan dua jenis tabungan yaitu tabungan yang berdasarkan prinsip mudarabah dan wadiah.

Dalil-dalil yang disampaikan fatwa tentang tabungan mencakup kutipankutipan dari ayat Al-Qur'an dan Hadis serta alasan menurut akal pikiran. Dalil akal pikiran bagi fatwa tentang tabungan pihak dinyatakan oleh para ulama bahwa perlu adanya kerjasama antara pihak yang kelebihan dana tetapi tidak bisa memproduktifkan dengan pihak yang kekurangan dan tetapi mempunyai kemampuan dalam memproduktifkannya..

Sama seperti fatwa tentang giro, dilihat dari segi metodologi, fatwa ini menggunakan dua metode sekaligus yaitu ijma dan qiyas. Metode ijma digunakan pada peristiwa sejumlah sahabat menyerahkan harta anak yatim sebagai mudarabah dan tidak ada seorangpun mengingkari mereka, sehingga hal tersebut dipandang sebagai ijma ${ }^{10}$ Sedangkan qiyas dipergunakan untuk menganalogikan antara mudarabah dengan transaksi musaqah.

\section{Fatwa Tentang Deposito}

Menimbang bahwa kegiatan deposito tidak semua dapat dibenarkan oleh hukum Islam, oleh karena itu dalam rangka memberikan pedoman dalam pelaksanaan deposito yaitu simpanan berjangka yang penarikanya hanya dapat dilakukan pada waktu tertentu berdasarkan perjanjian nasabah penyimpan dengan Bank, DSN hanya membenarkan deposito yang berdasarkan prinsip mudarabah. Fatwa ini ditetapkan oleh DSN dalam rangka merespon keperluan masyarakat dalam peningkatan kesejahteraan dan dalam bidang investasi.

Dalil-dalil yang dikemukakan tentang deposito meliputi kutipan ayat-ayat Al-Qur'an dan Hadis serta alasan menurut akal pikiran. Dalil akal pikiran dalam fatwa ini disampaikan oleh para ulama yang memandang perlu adanya kerjasama antara pihak yang surplus dana tetapi tidak bisa memproduktifitaskan dengan pihak yang minus dana tetapi mempunyai kemampuan untuk memperniagakan. Dipandang dari segi metodologi, fatwa tentang deposito ini menggunakan metode ijma' pada peristiwa sejumlah sahabat menyerahkan kepada mudarib harta anak yatim sebagai mudarabah, sedangkan terhadap kesepakatan tersebut tidak ada seorangpun yang mengingkari mereka. Adapun qiyas dipergunakan untuk membadingkan atau menganologika transaksi mudarabah dengan transaksi musaqoh.

\section{${ }^{10}$ Ibid.}


Dilihat dari segi metodologi, ketiga fatwa yang termasuk dalam fatwa produk penghimpunan dana perbankan syariah yaitu fatwa tentang giro, fatwa tentang tabungan, fatwa tentang deposito sama-sama menggunakan dalil dari kutipan ayat-ayat Al-Qur'an dan Hadis, dalil akal pikiran disampaikan oleh para ulama dan metode qiyas serta ijma ulama sebagai bahan pertimbangan penetapan giro, tabungan dan deposito yang diperbolehkan DSN. Adapun pola ijtihad yang dipergunakan DSN dalam menetapkan fatwa-fatwa tersebut adalah pola qiyasi ( $a^{\prime} l i l i$ ) dan pola istislahi. Pola ijtihad qiyasi digunakan pada saat menganalogikan transaksi mudarabah dengan transaksi musaqoh. Dalam hal ini sahibul mal (mudarabah dianalogikan dengan pemilik kebun/ladang dalam musaqoh dan pengelola (mudarib) dianalogikan dengan si penggarap kebun/ladang). Adapun pola istislahi (pertimbangan kemaslahatan berdasarkan nas umum) digunakan pada saat fatwa tersebut merespon kepentingan masyarakat dalam kegiatan perbankan yang berbasis syari'ah dan berlandaskan pada QS. An-Nisa' ayat 29, QS. al Baqarah ayat 283, QS. Al Maidah ayat $1-2$, QS al baqarah ayat $198 .{ }^{11}$

\section{B. Fatwa tentang Penyaluran Dana atau Pembiayaan yaitu :}

\section{Fatwa tentang Murabahab}

DSN menetapkan fatwa tentang murabahah ini dengan dasar pertimbangan bahwa masyarakat banyak memerlukan bantuan penyaluran dana dari bank syari'ah dengan prinsip jual-beli. Selain itu , fatwa ini juga merespon keperluan masyarakat guna melangsungkan dan meningkatkan kesejahteraan dan berbagai kegiatan. Oleh karena itu bank syari'ah memiliki fasilitas produk murabahah yaitu menjual suatau barang dengan menegaskan harga belinya kepada pembeli dan pembeli membayarnya dengan harga yang lebih sebagai keuntungan. Dalil-dalil yang dipakai dalam menetapkan murabahah ini terdiri dari kutipan-kutipan ayat Al-Qur'an dan Hadis. Dari segi metodologi fatwa tentang murabahah ini menggunakan metode ijma' yang diambil dari peristiwa mayoritas ulama tentang kebolehan jual beli dengan cara murabahah. ${ }^{12}$ Fatwa ini mengemukakan tentang ketentuan umum murabahah dalam Bank Syari' ah, ketentuan murabahah kepada nasabah, jaminan dalam murabahah, hutang dalam murabahah, penundaan pembayaran dalam murabahah serta peraturan apabila terjadi kebangkrutan dalam murabahah.

${ }^{11}$ Dewan Syari'ah Nasional MUI dan Bank Indonesia (2001), Himpunan Fatwa Dewan Syariah Nasional untuk Lembaga Keuangan Syariah, Edisi Pertama, hal. 0119.

${ }^{12}$ Ibnu Rusyd (tt), Bidayah al-Mujtahid, II / 161, lihat juga al-Kasani (tt), Badai as-Sanäi, V/220-222. 


\section{Fatwa tentang jual beli salam, jual beli istisna dan jual beli istisna paralel}

Fatwa tentang jual beli salam, jual beli istisna', dan jual beli istisna' paralel ditetapkan oleh DSN dengan beberapa pertimbangan bahwa pihak perbankan telah terlibat jual beli barang dengan cara pemesanan dan pembayaran harga lebih dulu dengan syarat-syarat tertentu yang disebut dengan salam. Selain itu masyarakat membutuhkan memperoleh sesuatu dengan melibatkan pihak lain untuk membuatnya dan hal seperti ini dapat dilakukan melalui jual beli istisna', yaitu akad jual beli dalam bentuk pemesanan pembuatan barang tertentu dengan kriteria dan persyaratan tertentu yang telah disepakati, antara pemesan (pembeli) dan penjual (pembuat). Jual beli istisna' yang dilakukan oleh lembaga keuangan syari'ah pada umumnya secara paralel yaitu sebuah bentuk akad istisna' antara nasabah dan Lembaga Keuangan Syari'ah, kemudian untuk memenuhi kewajibannya kepada nasabah, Lembaga Keuangan Syari'ah memerlukan pihak lain sebagai pembuat atau produsen. Fatwa ini juga dimaksudkan untuk memberi pedoman kepada perbankan syari' ah agar praktek syari'ah tersebut sesuai dengan dalil-dalil yang digunakan dalam menetapkan fatwa tentang jual beli salam, fatwa tentang istisna dan fatwa tentang istisna paralel ini terdiri dari kutipan ayat $\mathrm{Al}$ Qur'an dan Hadis. Dari segi metodologi fatwa tersebut menggunakan metode ijma' untuk penetapan fatwa jual beli salam.

Menurut Ibnu Munzir, ulama sepakat (ijma) atas kebolehan jual beli dengan cara salam. Di samping itu cara tersebut juga diperlukan oleh masyarakat ${ }^{13}$ Sedangkan untu fatwa istisna' dan istishna' paralel DSN berlandakan kepada pendapat madzab Hanafi. Sebenarnya, menurut pendapat madzab Hanafi ${ }^{14}$ bay' al-istisna termasuk akad yang dilarang karena bertentangan dengan semangat bay' secara qiyas. Mereka mendasarkan pada argumentasi bahwa pokok konrak penjualan harus ada dan dimiliki oleh penjual, sedangkan dalam istisna, pokok tersebut belum ada atau tidak dimiliki penjual. Meskipun demikian madzab Hanafi menyetujui kontrak istisna' atas dasar istihsan dengan alasan-alasan sebagai berikut :

a. Masyarakat telah mempraktekkan bay' al-istishna' secara luas dan terus menerus tanpa ada keberatan sama sekali. Hal demikian bay' al-istishna' sebagai kasus ijma' atau konsensus umum.

b. Di dalam syari'ah dimungkinkan adanya penyimpangan terhadap qiyas berdasarkan ijma ulama.

c. Keberadaan bay' al-istisna' diadasarkan atas kebutuhan masyarakat. Banyak orang seringkali membutuhkan barang yang tidak tersedia di pasar, sehingga mereka cenderung melakukan kontrak agar orang lain membuatkan barang untuk mereka.

${ }^{13}$ Wahbah Zuhaily (1989), al-Fiqh al-Islami wa Adillatuhu, hal. 598.

${ }^{14}$ al Kamal Ibnul Human dalam Muhammad Syafi'i Antonio (2001), Bank Syariah dari Teori ke Praktik, (Jakarta: GIP), hal.114. 
Rahmani Timorita Yulianti: Pola Ijtihad ...

d. Bay'al-istisna' sah sesuai dengan aturan umum mengenai kebolehan kontrak selama tidak bertentangan dengan nash atau aturan syari'ah ${ }^{15}$

\section{Fatwa tentang Pembiayaan Mudarabab (Qirad)}

Dasar pertimbangan ditetapkannya fatwa tentang pembiayaan mudarabah adalah memberikan pedoman bagi lembaga keuangan syari'ah agar pembiayaan mudarabah sebagai salah satu produk perbankan syari'ah sesuai dengan Syari'ah Islam

Pemberian pembiayaan dengan sistem mudarabah ini dalam rangka mengembangkan dan meningkatkan dana lembaga keuangan syari'ah termasuk perbankan syari'ah. Dengan sistem mudarabah, pihak perbankan syariah dapat menyalurkan dananya kepada pihak lain, yaitu suatu bentuk akad kerja sama suatu usaha dua pihak. Dalam hal ini pihak pertama (Sahibul Mal, LKS) menyediakan seluruh modal, sedang pihak kedua (amil/mudarib) nasabah, bertindak sebagai pengelola dan keuntungan usaha dibagi di antara mereka sesuai dengan kesepakatan yang dituangkan dalam kontrak.

Adapun dalil-dalil yang dipergunakan dalam penetapan fatwa tentang pembiayaan mudarabah terdiri dari kutipan-kutipan ayat Al-Qur'an dan Hadis. Dari segi metodologi, fatwa tersebut menggunakan metode ijma' dan qiyas. Metode ijma' digunakan karena sejumlah sahabat menyerahkan (kepada orang, mudarib) harta anak yatim sebagai mudarabah dan tidak ada seorangpun mengingkari mereka. Oleh karena itu peristiwa tersebut dipandang sebagai ijma'. Sedangkan metode qiyas digunakan ketika transaksi mudarabah diqiyaskan kepada transaksi musaqah ${ }^{16}$

\section{Fatwa tentang Pembiayaan Musyarakab}

Fatwa tentang pembiayaan musyarakah ini ditetapkan dengan maksud memenuhi kebutuhan masyarakat untuk meningkatkan kesejahteraan dalam berusaha. Pembiayaan musyarakah pembiayaan berdasarkan akad kerja sama antara dua pihak atau lebih untuk suatu usaha tertentu di mana masing-masing pihak memberikan kontribusi dana dengan ketentuan bahwa keuntungan dan risiko akan ditanggung bersama sesuai dengan kesepakatan. Fatwa tersebut juga dimaksudkan sebagai pedoman bagi perbankan syari'ah agar cara-cara yang dilakukan dalam pembiayaan musyarakah sesuai dengan prinsip-prinsip syariah Islam.

Dalil-dalil yang digunakan dalam penetapan fatwa tentang pembiayaan musyarakah ini adalah kutipan-kutipan dari ayat-ayat Al-Qur'an dan Hadis. Dari segi metodologi, fatwa ini hanya menggunakan metode ijma' ulama atas bolehnya musyarakah. Metode ijma’ yang digunakan dengan berdasar pada pendapat Ibnu

${ }^{15}$ Ibid.

${ }^{16}$ Wahbah Zuhaily (1989), al-Fiqh al-Islami wa Adillatuhu, hal. 838. 
Qudamah dalam kitabnya Al-Mugni bahwa, kaum muslimin telah berkonsensus terhadap legitimasi musyarakah secara global walaupun terdapat perbedaan pendapat dalam beberapa elemen darinya ${ }^{17}$. Ijma' ulama ini lebih diperkuat dengan adanya taqrir Nabi terhadap kegiatan musyarakah yang dilakukan oleh masyarakat pada saat itu ${ }^{18}$

\section{Fatwa tentang Pembiayaan Ijarab}

Penetapan fatwa tentang pembiayaan ijarah dilaunchingkan dengan pertimbangan bahwa kebutuhan masyarakat untuk memperoleh manfaat suatu barang sering memerlukan pihak lain melalui akad ijarah, yaitu akad pemidahan manfaat suatu barang atau jasa dalam waktu tertentu melalui pembayaran sewa/ upah, tanpa diikuti dengan pemindahan kepemilikan barang bukti. Berdasarkan hal tersebut perbankan syari'ah dapat melayani melalui salah satu produknya yaitu pembiayaan ijarah. Agar akad tersebut sesuai dengan ajaran Islam, maka DSN memandang perlu menetapkan fatwa ini sebagai pedoman bagi LKS khususnya perbankan syariah.

Ladasan hukum yang digunakan dalam penetapan fatwa tentang pembiayaan ijarah ini yaitu kutipan-kutipan ayat Al-Qur'an dan Hadis. Dilihat dari sisi metodologi, fatwa ini menggunakan metode ijma' karena pakar-pakar keilmuan dan cendekiawan sepanjang sejarah di seluruh negeri telah sepakat akan legitimasi ijma'. Ijma' ini dipertegas dengan kaidah fiqhiyah bahwa pada dasarnya semua bentuk mu'amalah boleh dilakukan kecuali dalil yang mengharamkannya serta dimaksudkan untuk lebih mendahulukan atas mendatangkan kemaslahatan dan menghindarkan mafsadat/kerusakan/bahaya.

\section{Fatwa tentang Al-Ijarab Muntabiyab Bi Al-Tamlik}

Fatwa ini ditetapkan dengan pertimbangan bahwa dewasa ini dalam masyarakat telah umum dilakukan praktik sewa beli, yaitu perjanjian sewa menyewa yang disertai dengan opsi pemindahan hak milik atas benda yang disewa kepada penyewa setelah selesai masa sewa. Selain itu fatwa ini dimaksudkan untuk memberi pedoman kepada perbankan Syari'ah dalam operasionalisasi produknya agar sesuai dengan Syari'ah.

Dalam penetapan fatwa ini menggunakan dalil-dalil yang meliputi kutipan dari ayat-ayat Al-Qur'an dan Hadis. Secara metodologis, fatwa ini merujuk kepada fatwa tentang pembiayaan ijarah yang menggunakan metode ijma'. Dalam akad ijarah tidak diikuti dengan pemindahan kepemilikan barang. Sedangkan akad al-Ijarah Muntahiyah bi al-Tamlik disertai opsi pemindahan hak milik atas benda yang disewa kepada penyewa, setelah selesai masa sewa.

${ }^{17}$ Abdullah Ibnu Ahmad Ibnu Qudamah (1979), Mughni wa Syarh kabir, vol.V, (Beirut: Darul Fikr), hal. 109.

${ }^{18}$ Dewan Syari'ah Nasional MUI dan Bank Indonesia (2001), Himpunan Fatwa Dewan Syariah Nasional untuk Lembaga Keuangan Syariah, Edisi Pertama, hal. 58. 
Sebagaimana fatwa pembiayaann ijarah, fatwa ini dikuatkan dengan kaidah fiqhiyah bahwa pada dasarnya segala bentuk mu'amalah boleh dilakukan kecuali dalil yang mengharamkannya serta kaidah fiqhiyah yang menyatakan bahwa di mana terdapat kemaslahatan di sana terdapat hukum Allah. ${ }^{19}$

\section{Fatwa tentang Al-Qard}

Penetapan fatwa tentang Al-Qard ini dengan pertimbangan bahwa perbankan Syariah sebagai Lembaga Keuangan Syari'ah di samping sebagai lembaga komersial, harus dapat berperan sebagai lembaga sosial yang dapat meningkatkan perekonomian secara maksimal.

Oleh karena itu salah satu sarana peningkatan perekonomian dapat dilakukan oleh perbankan Syari'ah adalah dengan penyaluran dana melalui prinsip al-Qard yaitu suatu akad pinjaman kepada nasabah dengan ketentuan bahwa nasabah wajib mengembalikan dana yang diterimanya kepada perbankan Syari'ah pada waktu yang telah disepakati oleh perbankan Syari'ah dengan nasabah. Fatwa ini juga dimaksukan sebagai pedoman perbankan Syari'ah agar akad al-Qard sesuai dengan Syari'ah Islam

Dalam hukum penetapan fatwa ini menggunakan kutipan ayat-ayat Al-Qur'an dan Hadis serta kaidah fiqhiyah yaitu, setiap utang piutang yang medatangkan manfaat (bagi yang berpiutang) adalah riba ${ }^{20}$. Oleh karena itu, dalam pengembalian pinjaman $A l$-Qard nasabah hanya membayar jumlah pokok yang diterima. Dan dapat memberikan tambahan (sumbangan) dengan suka rela kepada perbankan syari'ah selama tidak tidak diperjanjikan dalam akad ${ }^{21}$. Dari ke 9 fatwa yang termasuk dalam fatwa tentang produk penyaluran sebagaimana dipaparkan di atas, dapat dipahami bahwa pola ijtihad yang digunakan oleh DSN dalam menetapkan fatwa-fatwa tersebut adalah pola istislahi yaitu pola ijtihad yang mengidentifikasi masalah-masalah yang tidak mempunyai nas khusus sebagai rujukan. Dalam pola ini ayat-ayat umum dikumpulkan guna menciptakan beberapa prinsip umum yang digunakan untuk melindungi atau mendatangkan kemaslahatan tertentu. Kemudian prinsip umum tersebut dideduksikan kepada persoalan yang ingin diselesaikan.

Persoalan-persoalan tersebut adalah jual beli dengan cara murabahah, jual beli dengan cara salam, jual beli dengan cara istishna, maupun istishna paralel, pembiayaan mudarabah, musyarakah, ijarah, ijarah muntahiyah bi al-tamlik dan al-qard. Persoalan-persoalan tersebut tidak mempunyai nas khusus sebagai rujukan. Oleh karena itu, untuk menentukan hukumnya, digunakan prinsipprinsip umum yang ditarik dari ayat-ayat Al-Qur'an, Al Hadis, dan Qaidah Fiqhiyah.

${ }^{19}$ Dewan Syari'ah Nasional MUI dan Bank Indonesia (2001), Himpunan Fatwa Dewan Syariah Nasional untuk Lembaga Keuangan Syariah, Edisi Pertama, hal. 02.

${ }^{20}$ Ibid, hal.107

${ }^{21}$ Ibid. 
Dari prinsip-prinsip umum tersebut, melalui pendeduksian dan pertimbangan tingkatan keutamaan seperti daruriyat (kebutuhan esensial), hajiyat (kebutuhan sekunder), dan tahsiniyat (kebutuhan kemewahan), para ulama yang berada dalam Dewan Syari'ah Nasional MUI menyimpulkan kebolehan peluncuran dan pengembangan produk pembiayaan perbankan Syari'ah melalui fatwa-fatwanya. Pada produk pembiayaan ini DSN juga menggunakan pola qiyasi pada saat menganalogikan transaksi mudarabah kepada transaksi musaqah.

\section{Fatwa Tentang Jasa Perbankan Syari'ah}

\section{Fatwa tentang Wakalab}

Fatwa ini ditetapkan dengan maksud agar praktik wakalah yang dilakukan di perbankan syari'ah sesuai dengan ajaran Islam. Wakalah dilakukan pada perbankan syari'ah sebagai salah satu bentuk pelayanan jasa perbankan syari'ah kepada nasabahnya. Dalam rangka mencapai suatu tujuan sering diperlukan pihak lain untuk mewakilinya melalui akad wakalah, yaitu pelimpahan kekuasaan oleh satu pihak kepada pihak lain dalam hal-hal yang boleh diwakilkan.

Dali-dalil yang dipakai sebagai landasan hukum penetapan fatwa wakalah ini adalah kutipan ayat-ayat Al-Quran dal Al Hadis. Secara metodologis fatwa ini menggunakan metode ijma'. Metode ijma' digunakan karena para ulama bersepakat atas dibolehkannya wakalah. Mereka bahkan ada yang cenderung mensunahkan dengan alasan bahwa wakalah termasuk jenis ta'awun atau tolong menolong atas dasar kebaikan dan taqwa ${ }^{22}$.

Ijma’ para ulama diperkuat dengan kaidah fiqhiyah bahwa pada dasarnya, semua bentuk mu'amalah boleh dilakukan kecuali yang mengharamkannya ${ }^{23}$

\section{Fatwa tentang Kafalab (Guaranty)}

Penetapan fatwa tentang kafalah ini diadakan dengan pertimbangan untuk memenuhi kebutuhan masyarakat dalam bertransaksi dengan orang lain. Dalam menjalankan usahanya seseorang sering memerlukan pinjaman dari pihak lain melalui akad kafalah, yaitu jaminan yang diberikan oleh penanggung ( $k a f i l)$ kepada pihak ketiga untuk memenuhi kewajiban pihak kedua atau yang ditanggung (makful 'anhu, ashil). Dalam rangka mengakomodir kebutuhan masyarakat tersebut perbankan Syariah berkewajiban menyediakan satu skema penjamin (kafalah) yang berdasarkan prinsip-prinsip Syariah. Sesuai dengan tugasnya maka DSN memandang perlu menetapkan fatwa tentang kafalah untuk dijadikan pedoman oleh LKS pada umumnya dan perbankan Syari'ah pada khususnya.

${ }^{22}$ Wahbah Zuhaily (1989), al-Figh al-Islami wa Adillatuhu, hal. 4060-4061.

${ }^{23}$ Dewan Syari'ah Nasional MUI dan Bank Indonesia (2001), Himpunan Fatwa Dewan Syariah Nasional untuk Lembaga Keuangan Syariah, Edisi Pertama, hal.66. 
Sebagaimana fatwa DSN yang terdahulu, fatwa tentang kafalah ini menggunakan dalil-dalil meliputi kutipan ayat-ayat Al-Qur'an dan Hadis. Ayat-ayat Al-Qur'an dan Hadis-hadis tersebut kemudian dikuatkan dengan kaidah fiqhiyah seperti, "pada dasarnya, semua bentuk mu'amalah boleh dilakukan kecuali ada dalil yang mengharamkanya", serta " bahaya / beban berat harus dibilangkan"24

\section{Fatwa tentang Hawalah (Transfer Service)}

Pertimbangan ditetapkanya fatwa hawalah oleh DSN ini adalah berangkat dari suatu kondisi bahwa terkadang seseorang tidak dapat membayar hutanghutangnya secara langsung, oleh karena itu orang tersebut memindahkan penagihannya kepada pihak lain yang dalam hukum Islam disebut dengan hawalah yaitu akad pengalihan hutang dari satu pihak yang berhutang kepada pihak lain yang wajib menanggung (membayar)-nya.

Atas kebutuhan masyarakat tersebut direspon perbankan Syari'ah melalui produk hawalah (transfer service) yang sesuai dengan ajaran Islam.

Landasan syari'ah fatwa ini adalah kutipan dari hadis saja tanpa menggunakan dalil-dalil kutipan dari ayat Al- Qur'an. Secara metodologi DSN menggunakan metode ijma dalam penetapan fatwa tentang hawalah. Metode ijma digunakan karena ulama sepakat membolehkan hawalah. Hawalah dibolehkan pada utang yang tidak berbentuk barang/benda karena hawalah adalah perpindahan hutang. Oleh karena itu harus ada uang atau kewajiban finansial ${ }^{25}$. Dari landasan syari'ah yang berupa hadis dan ijma ulama tersebut DSN menguatkan dengan kaidah fiqhiyah yaitu "pada dasarnya semua bentuk mu'amalah boleh dilakukan kecuali ada dalil yang mengharamkanya", serta "bahaya / beban berat harus dihilangkan" 26

\section{Fatwa tentang Safe Deposit Box}

Fatwa ini dilaunchingkan dengan pertimbangan bahwa salah satu jasa perbankan syari'ah yang menjadi kebutuhan masyarakat adalah menyediakan tempat penyimpanan barang berharga atau dikenal dengan istilah safe deposit Box (SDB). Jasa tersebut harus sesuai dengan prinsip syari'ah oleh karena itu DSN berkewajiban mengeluarkan fatwa tentang safe deposit box sebagai pedoman perbankan Syari'ah dalam operasionalnya.

Dalil-dalil yang digunakan DSN dalam penetapan fatwa ini adalah kutipan ayat-ayat Al Qur'an dan Hadis Rasulullah saja. Secara metodologis fatwa ini tidak menggunakan metode ijtihad karena berdasarkan sifat dan karakternya, safe deposit box dilakukan dengan menggunakan akad ijarah (sewa). Sehingga

${ }^{24}$ Ibid, hal.72.

${ }^{25}$ Wahbah Zuhaily (1989), al-Figh al-Islami wa Adillatuhu, hal.418.

${ }^{26}$ Dewan Syari'ah Nasional MUI dan Bank Indonesia (2001), Himpunan Fatwa Dewan Syariah Nasional untuk Lembaga Keuangan Syariah, Edisi Pertama, hal.76-77. 
rukun dan syarat ijarah dalam pratik SDB merujuk pada fatwa DSN tentang pembiayaan ijarah. Sehingga secara metodologis fatwa ini menggunakan metode ijma, yaitu kesepakatan ulama atas kebolehan ijarah (sewa) ${ }^{27}$

\section{Fatwa tentang Pengaliban Hutang}

Salah satu bentuk jasa pelayanan keuangan yang menjadi kebutuhan masyarakat adalah membantu masyarakat untuk mengalihkan transaksi nonsyari'ah yang telah berjalan menjadi transaksi yang sesuai dengan syari'ah. Atas kebutuhan masyarakat tersebut perbankan syariah perlu merespon dalam berbagai produknya melalui akad pengalihan hutang. Oleh karena itu DSN memandang perlu menetapkan fatwa mengenai hal tersebut untuk dijadikan pedoman bagi LKS umumnya dan perbankan syari'ah khususnya.Landasan Syari'ah yang digunakan adalah kutipan ayat-ayat Al Qur'an dan Hadis serta qaidah fiqhiyah ${ }^{28}$

\section{Fatwa tentang Letter of Credit(L/C) Impor Syari'ab}

Agar mekanisme transaksi L/C impor tersebut dilakukan sesuai dengan prinsip-prinsip Syari'ah, Dewan Syari'ah Nasional memandang perlu menetapkan fatwa mengenai hal tersebut untuk dijadikan pedoman bagi perbankan Syariah. Fatwa ini penting karena transaksi L/C impor yang berlaku selama ini belum sesuai dengan ketentuan Syari'ah. Letter of Credit $(L / C)$ impor syari'ah adalah surat pernyataan akan membayar kepada eksportir yang diterbitkan oleh bank untuk kepentingan importer dengan pemenuhan persyaratan tertentu sesuai dengan prinsip Syari'ah. L/C impor syariah dalam pelaksanaannya menggunakan akad-akad wakalah bil Ujrah, Qard, Murabahah, Salam/Istisna, Mudarabah, Musyarakah dan Hawalah. Oleh karena itu fatwa tentang L/C impor Syari'ah ini merujuk kepada fatwa DSN tentang Ijarah, Qard, Murababah, Salam/Istisna,' Mudharabah, Musyarakah dan Hawalah.

Adapun dalil-dalil yang digunakan dalam fatwa ini meliputi kutipan ayatayat Al Qur'an, Al Hadis dan kaidah fiqhiyah yang terdapat pada fatwa DSN tentang Ijarah, Qard, Murabahah, Salam/Istisna', Mudarabah, Musyarakah dan Hawalah.

\section{Fatwa tentang Letter of Credit Ekspor Syariab}

Selain L/C impor Syari'ah, perbankan Syariah juga memberikan jasa fasilitas transaksi ekspor yang dilakukan oleh nasabah, yang dikenal dengan istilah Letter of Credit (L/C) ekspor Syariah. Agar jasa yang diberikan oleh perbankan Syari'ah dilakukan sesuai dengan prinsip-prinsip Syari'ah DSN memandang perlu menetapkan fatwa mengenai hal tersebut untuk dijadikan pedoman.

\footnotetext{
${ }^{27}$ Ibid.

${ }^{28}$ Ibid (2002), tanpa hlm.
} 
Sebagaimana fatwa tentang L/C impor, fatwa ini merujuk kepada fatwa DSN MUI mengenai Ijarah, Qrad, Mudarabah dan Musyarakah. Selain mengenai dalil-dalil yang digunakan dan pola ijtihad yang dilakukan DSN, didasarkan kepada fatwa tersebut.

Dari 7 (tujuh) fatwa yang termasuk dalam fatwa tentang produk jasa perbankan syari'ah seperti pada deskripsi di atas, dapat dipahami bahwa pola ijtihad yang digunakan oleh DSN dalam menetapkan fatwa-fatwa tersebut adalah sama dengan pola Ijtihad yang digunakan oleh DSN pada saat menetapkan fatwa produk penyaluran/pembiayaan yaitu pola istislahi. Dengan pola istislahi ini DSN mengidentifikasi masalah-masalah bentuk-bentuk transaksi yang tidak mempunyai nash khusus sebagai rujukan. Dalam menggunakan pola istislahi ini, DSN mengumpulkan ayat-ayat umum guna menemukan prinsip-prinsip umum yang digunakan untuk melindungi atau mendatangkan kemaslahatan. Kemudian prinsip umum tersebut dideduksikan kepada persoalan atau produk perbankan syari'ah yang akan diluncurkan oleh DSN. Persoalan atau transaksi yang terdapat dalam bentuk jasa perbankan syari'ah tersebut adalah : Wakalah, Kafalah, Hawalah, Jasa Save Deposit Box, Pengalihan Hutang, Letter of Credit Impor dan Letter of Credit Ekspor. Dalam menentukan hukumnya, digunakan prinsip-prinsip umum yang ditarik dari ayat-ayat Al Qur'an, Al Hadis, dan Qaidah Fiqhiyah.

Dari prinsip-prinsip umum tersebut, sebagaimana yang dilakukan DSN dalam menetapkan fatwa-fatwa tentang produk pembiayaan, dalam menetapkan fatwa produk jasa, dilakukan pendeduksian dan pertimbangan tingkatan keutamaan seperti daruriyat (kebutuhan esensial), hajiyat (kebutuhan sekunder), dan tahsiniyat (kebutuhan kemewahan). Berdasarkan hal tersebut, DSN MUI menyimpulkan kebolehan peluncuran dan pengembangan produk jasa perbankan Syari'ah melalui fatwa-fatwanya.

Dari deskripsi dalil-dalil dan prinsip-prinsip umum yang digunakan oleh DSN dalam menetapkan fatwa tentang produk perbankan Syari'ah tersebut dapat diklasifikasikan pola-pola ijtihad yang dipakai DSN sebagai berikut : Pola Ijtihad Qiyasi (Ta'lili) dan pola ijtihad Istislahi

\begin{tabular}{|c|l|l|}
\hline No & \multicolumn{1}{|c|}{ Nama Produk } & \multicolumn{1}{c|}{ No. Fatwa } \\
\hline 1. & Giro & $01 / \mathrm{DSN}-\mathrm{MUI} / \mathrm{IV} / 2000$ \\
\hline 2. & Tabungan & $02 / \mathrm{DSN}-\mathrm{MUI} / \mathrm{IV} / 2000$ \\
\hline 3. & Deposito & $03 / \mathrm{DSN}-\mathrm{MUI} / \mathrm{IV} / 2000$ \\
\hline 4. & Mudarabah & $04 / \mathrm{DSN}-\mathrm{MUI} / \mathrm{IV} / 2000$ \\
\hline 5. & Jual Beli Saham & $05 / \mathrm{DSN}-\mathrm{MUI} / \mathrm{IV} / 2000$ \\
\hline 6. & Jual Beli Istishna & $06 / \mathrm{DSN}-\mathrm{MUI} / \mathrm{IV} / 2000$ \\
\hline
\end{tabular}


Rahmani Timorita Yulianti: Pola Ijtihad ...

\begin{tabular}{|c|l|l|}
\hline No & \multicolumn{1}{|c|}{ Nama Produk } & \multicolumn{1}{|c|}{ No. Fatwa } \\
\hline 7. & Jual Beli Istishna' Pararel & 22/DSN-MUI/III/2000 \\
\hline 8. & Pembiayaan Mudarabah & 07/DSN-MUI/IV/2000 \\
\hline 9. & Pembiayaan Musyarakah & 08/DSN-MUI/IV/2000 \\
\hline 10. & Pembiayaan Ijarah & 09/DSN-MUI/IV/2000 \\
\hline 11. & Ijarah Muntahiyah Bil Al Tamlik & 271/DSN-MUI/IV/2000 \\
\hline 12. & Al Qardh & 19/DSN-MUI/IV/2000 \\
\hline 13. & Wakalah & 10/DSN-MUI/IV/2000 \\
\hline 14. & Kafalah & 11/DSN-MUI/IV/2000 \\
\hline 15. & Hawalah & 12/DSN-MUI/IV/2000 \\
\hline 16. & Save Deposit Box & 24/DSN-MUI/III/2000 \\
\hline 17. & Pengalihan Hutang & 31/DSN-MUI/VI/2000 \\
\hline 18. & Letter of Credit Impor & 345/DSN-MUI/XI/2000 \\
\hline 19. & Letter of Credit Expor & 35/DSN-MUI/XI/2000 \\
\hline
\end{tabular}

Dari deskripsi terdahulu dapat dipahami bahwa keberadaan pengembangan produk-produk perbankan syari'ah sejak awal berdirinya sampai sekarang sangat dibutuhkan oleh masyarakat. Sejalan dengan upaya restrukturisasi perbankan yang sedang dilaksanakan dewasa ini, yaitu membangun kembali sistem perbankan yang sehat dalam rangka mendukung program pemulihan dan kebangkitan ekonomi sosial, maka salah satu upaya yang dilakukan untuk mengoptimalkan fungsi sistem perbankan, adalah pengembangan sistem perbankan syari'ah melalui produk-produknya.

Selain itu, sistem perbankan syari'ah yang merupakan pola pembiayaan usaha dengan prinsip bagi hasil pada produk-produknya sebagai salah satu pokok dalam kegiatan perbankan syari'ah juga akan menumbuhkan rasa tanggung jawab pada masing-masing pihak, baik bank maupun nasabahnya, sehingga dalam menjalankan kegiatannya semua pihak pada hakekatnya akan memperhatikan prinsip kehati-hatian dan akan memperkecil kemungkinan resiko terjadinya kegagalan usaha. Berdasarkan kepada aspek pemenuhan kebutuhan masyarakat akan produk dan jasa perbankan Syari'ah, maka DSN sudah seharusnya memberikan fatwa bagi pengadaan dan pengembangannya. DSN yang di dalamnya terdiri dari para ulama, mempunyai kunci dalam pengembangan produk perbankan Syari'ah.

Dari paparan tersebut dapat disimpulkan bahwa latar belakang pertimbangan penetapan fatwa Dewan Syari'ah Nasional adalah pemenuhan kebutuhan masyarakat akan transaksi di bidang mu'amalah maliyah yang berdasarkan kepada prinsip Syari'ah. 
Rahmani Timorita Yulianti: Pola Ijtihad ...

\section{Penutup} berikut :

Dari beberapa paparan terdahulu dapat disimpulkan beberapa hal sebagai

A. Pola ijtihad yang dipergunakan oleh Dewan Syari'ah Nasional MUI dalam penetapan fatwa tentang produk perbankan syari'ah adalah pola qiyasi (ta'lili) dan pola istislahi.

B. Adapun faktor yang melatarbelakangi pertimbangan penetapan fatwa Dewan Syari'ah Nasional MUI tentang produk perbankan Syari'ah adalah :

1. Untuk memenuhi kebutuhan jasa perbankan bagi masyarakat yang tidak dapat menerima konsep bunga. Serta sebagai peluang pembiayaan bagi pengembangan usaha berdasarkan prinsip kemitraan.

2. Kebutuhan akan produk dan jasa perbankan yang memiliki keunggulan yang unik dan berdasarkan kepada nilai-nilai moral. Keunggulan ini antara lain berupa peniadaan pembebanan bunga yang berkesinambungan, pembiayaan ditujukan kepada usaha yang lebih mencegah terjadinya kerusakan lingkungan dan kerusakan moral.

\section{DAFTAR PUSTAKA}

Nabhani, Taqyuddin An (1996). Membangun Sistem Ekonomi Alternatif Perspektif Islam. Surabaya: Risalah gusti.

Antonio, Muhammad Syafii' (1999). Bank Syariah : Bagi bankir dan Praktisi Keuanga. Jakarta : Bank Indonesia dan Tazkia Institue.

- (1999). Bank Syari' ah: Wacana Ulama dan Cendekiawan. Jakarta : Bank Indonesia dan Tazkia Institue.

- (1999). Bank Syari' ah: Wacana Ulama dan Cendekiawan. Jakarta : Bank Indonesia dan Tazkia Institue.

-..--.-- (2001).Bank Syari'ah: Dari Teori ke Praktek. Jakarta : gema Insani Press.

Arifin, Zaenul (1999). Memahami Bank Syari'ah Lingkup, Peluang, Tantangan dan Prospek. Jakarta : Alvabet.

Chapra, M. Umer (1997). Al-Qur'an Menuju Sistem Moneter yang Adil. terj. Lukman Hakim. Yogyakarta : PT. Dana Bhakti Prima Yasa.

-.----- (1999). Islam dan Tantangan Ekonomi. Surabaya: Risalah Gusti.

Dewan Syari' ah Nasional Majelis Ulama Indonesia dan Bank Indonesia (2001). Himpunan Fatwa Dewan Syariah Nasional. Edisi Pertama. Jakarta.

Ibnu Rusyd (tt). Bidayah al-Mujtahid, II.

al-Kasani (tt). Bada’i as-Sana’i, V.

Kafh, Monzer (1995). Ekonomi Islam : Telaah Analitik Terhadap Fungsi Sistem Ekonomi Islam. Yogyakarta : Pustaka Pelajar. 
Rahmani Timorita Yulianti: Pola Ijtihad ...

Karim, Adiwarman (2003). Bank Islam Analisis Fiqh dan Keuangan. Jakrta : The International Institute of Islamic Thought Indonesia.

Mannan, M. Abdul (1997). Ekonomi Islam : Teori dan Praktek. Yogyakarta : Dana Bakti Wakaf.

Muhammad (2000). Sistem dan Prosedur Operasional Bank Islam. Yogyakarta : UII Press.

---.--- (2001). Teknik Perhitungan Bagi Hasil di Bank Syariah. Yogyakarta : UII Press.

Mu'allim, Amir dan Yusdani (2001). Konfigurasi Pemikiran Hukum Islam Di Indonesia. Cetakan kedua.Yogyakarta: UII Press.

Mudzhar,Muhammad Atho (1993). Fatwa-fatwa Majelis Ulama Indonesia: Sebuah Studi Tentang Pemikiran Hukum Islam Di Indonesia 1975-1988. Jakarta: INIS.

-_-_---- (2000). Membaca Gelombang Ijtihad: Antara Tradisi dan Liberasi. Cetakan ke-2.Yogyakarta: TIP.

--.---- (1998). Pendekatan Studi Islam dalam Teori dan Praktik. Cetakan ke-2. Yogyakarta: Pustaka Pelajar Offset.

Ma'ruf, Ad Dawalibi Muhammad (1965). al-Madkhal ila 'ilm Usul al-

Figh.Beirut:Dar al-'Ilm lil-Malayin.

Zuhaily, Wahbah (1989), al-Figh al-Islami wa Adillatuhu. 